step in the building up of our defence policy should be to recreate as quickly as possible the alliance of peace-loving powers in the League of Nations. $\mathrm{He}$ also urges the importance in rearmament of simultaneous attention to the problem of unemployment. By a full utilization of the labour-power of those now unemployed and by the elimination of waste due to competitive redundancy in production and distribution, we could increase our production of armaments and of consumers' goods as well. The available labour power and capital resources of the nation should be distributed according to a plan of increased national productivity. Defence preparations, he insists, involve consideration of overseas trade and our general economic relations with other countries; the productive efficiency of our economic system as a whole; the accumulation of supplies of storable foodstuffs and raw material and technical questions regarding the kind of war material to be produced, the location of the necessary factories and the organization of reserve productive capacity.

Mr. MacmmLan urges the creation of a single authoritative foreign trade organization which, under the general direction of the Overseas Trade Department, would bring together and combine the activities of the Import Duties Advisory Committee, the experts in charge of the Exchange Equalisation Fund's operations, representatives of finance to advise on foreign lending, and representatives of the exporters' selling organizations and of the importers' buying organizations. He reiterates the plea for a National Economic Council and urges an Industrial Reorganisation (Enabling) Act to afford industry the opportunity of putting its own house in order and achieving the necessary output, and discusses in some detail an attack on the unemployment problem. A Ministry of Supply is regarded as essential, and Mr. Macmillan stresses the compatibility of his proposals with the promotion of social and individual freedom. In his final chapter on nationalism or internationalism, he argues that a policy of static resistance is not enough. If a correct foreign policy sustained by adequate economic and military strength is the first task, this must be followed by the creation of the national foreign trade organization supported by a powerful internal economic organization conducted on rational lines for the full utilization of our capital and labour resources. These measures would enable us to evolve a method of economic collaboration which would eliminate the causes of war.

\section{Social and Political Implications of Science}

CoNTINUOUs survey and co-ordination of teaching and research work of the University in the natural and social sciences in terms of its relation to the political and social problems of the day-such was the task undertaken in 1933 by a group of faculty members of the University of Wisconsin. They established an organization known as the "Science Inquiry" which has had the effect of concentrating the attention of much of the University staff on scientific problems facing the State and the nation.
A guiding principle has been that attacks upon such problems should be comprehensive rather than departmental so that instead of fragmentary findings "there may emerge at least the beginnings of integrated, programmes with improved perspective and balance and with the application of these problems to State needs kept to the front"'. Among its publications are bulletins on the regional approach to conservation of natural resources, on transportation, and on the fight against crime; also (in preparation) international relations, public utility and power regulations, technological unemployment, communications, and consumption from the points of view of the producer and consumer. It is claimed on behalf of "Science Inquiry" that it has "evolved a group consciousness on the part of the faculty of common human problems which already is having a notable influence on the direction and emphasis of individual activities in teaching as well as research at the University".

\section{U.S. National Youth Administration}

A REPORT prepared for the Advisory Committee on Education of the United States by P. O. Johnson and O. L. Harvey on the National Youth Administration describes the organization and programme of the work of the Administration with a brief evaluation of some of its achievements. The National Youth Administration was set up as an agency within the Works Progress Administration in June 1935 and is thus primarily a relief agency, operating with funds earmarked for the general appropriation by Congress for emergency relief. Its two chief programmes are student aid and work projects, and its detailed operation in the several States varies according to local needs and problems. The number of young persons between 16 and 24 years of age receiving aid on the major programmes rose from about 470,000 a month in the first six months of 1936 to 580,000 a month in the same period of 1937 but has since declined owing to the reduction in the total budget. The student aid programme provides for those youths who are otherwise financially unable to continue their schooling. The works projects programme provides work experience for those whose interest in further schooling is relatively weak but who require work experience as a qualification for admission to private employment and earning a living. The guidance and placement service gives vocational guidance and attempts to place unemployed youth in employment. The apprentice-training programme was only an incidental function of the National Youth Administration and has recently been transferred to the Department of Labour. The programme of educa. tional camps for unemployed women proved expensive to maintain and has been terminated for this and other reasons. The experiments have directed attention to many inadequacies in the provision for vocational guidance and, apart from the prevention of demoralization or restoration of morale, the National Youth Administration has demonstrated the possibilities of concerted action in the solution of the problems of youth, and particularly the value of proper direction and wise planning. 